\title{
THE STRUCTURAL EVOLUTION OF THE BANKING SYSTEM IN ROMANIA UNDER THE IMPACT OF FDI
}

\author{
Vasile Cocriş ${ }^{1}$, Maria-Ramona Sârbu ${ }^{2 *}$ \\ ${ }_{1,2}$ Department of Finance, Money and Public Administration, Faculty of Economics and \\ Business Administration, „Alexandru loan Cuza” University of lasi, lasi, Romania \\ vcocris@uaic.ro \\ sarbumariar@gmail.com
}

\begin{abstract}
Foreign banks represent important channels for the transfer of productive resources, managerial and organizational skills and experience accumulated on international level, which led to increased competition in the banking market in Romania, which contributed to some extent to the profitability of the Romanian banking sector. The purpose of the current attempt of research is the analysis of the structural evolution of the banking sector in Romania, under the impact of foreign direct investments (FDI). Analyzing the structural evolution of the Romanian banking sector, there can be observed that in 2015, FDI has influenced some important merger operations on a level with branches of foreign banks in Romania, and over $85 \%$ of the total capital of the banking system in our country belongs to credit institutions with foreign majority ownership and to their branches. Regarding the origin of the foreign capital of credit institutions, it originates from the member states of the European Union (EU). It is also worthy of note that in 2015, the top ten banks in the banking sector of Romania held $71.6 \%$ of the assets, while the remaining 26 banks held a share of only $28.4 \%$ of the market. Banca Comercială Română, BRD - Groupe Société Générale and Banca Transilvania are in 2015 the main banks in the Romanian banking system, with a major market share.
\end{abstract}

Keywords: credit institutions, market share, Herfindahl - Hirschman Index, profitability, structural developments.

JEL classification: F21, G21, G31.

\section{Introduction}

In the last years, the entrance on the market of foreign banks has contributed to the development and progress of the Romanian banking system, thus fulfilling an important role in the Romanian economy. In this context, the purpose of the current paper is the analysis of the structural evolution of the banking sector in Romania, under the impact of FDI.

Because of the globalization phenomenon and the growing financial integration, many foreign banks have entered the market of developing countries. Although most foreign banks are coming from countries with a high income, recently the banks in developing countries have followed their example (Van Horen, 2007). The availability of resources and the international experience already gained by the mother-banks have a positive effect on their decision to carry out direct investment abroad (Mutinelli and Piscitello, 2001). Thus, an increasing share of the banking sector is controlled by foreign capital in most crossover countries, where on average, foreign owned banks are more efficient than domestic owned banks (Weill, 2003). Simpasa (2013), evaluates the degree of competition in the Zambian banking sector, using the Panzar-Rosse $\mathrm{H}$-statistic and the Lerner Index, as a way to

\footnotetext{
* Corresponding author
} 
measure competition. The findings of the study show that the entry of foreign banks and privatisation of the state-owned bank can intensify competitive pressures in the banking industry. Banks appear beyond frontiers also because economies differ in their endowment with production factors and in the efficiency of their banking sectors. From this perspective, international connections between banks played a crucial role in today's global economy (Niepmann, 2015). To the boost of FDI activity have also contributed the lower costs of the local credit and the increase of local competition between local banks in each country through the deregulation of the interstate banking (Kandilov et. al., 2016). As foreign banks are more competitive than local banks, the entry of the foreign capital in the banking sector is important through its contribution in creating the competitive nature of the market (Mulyaningsih et. al., 2015). In this context, Morutan and Badulescu (2016) also point out that the entry is relevant for the development of the banks, but less than in the previous period, when banks entered the emerging markets of the Central and Eastern European (CEE) countries. Thus, many CEE economies are characterized by a very competitive position and successful corporate sectors, supported by a very high level of FDI penetration (Popovici, 2013: 571). Balaj (2015), compared financial performance of the domestic and foreign banks in the banking sector of Kosovo during the period of 2001-2007, using the DuPont financial analysis model in order to measure the comparative performance between domestic and foreign banks. The results from the research study showed, that foreign banks had been more efficient and profitable, thus having a higher ratio of Return on Assets (ROA) and Return on Equity (ROE), outlining that the foreign banks' high ratio of Return on Equity is a result of a higher interest margin, which suggest that foreign banks have made a better costs management and a larger use regarding financial leverage. Ghosh (2016), using data on MENA banks for 2000-2012, examines how foreign bank presence impacts domestic bank performance. The author also analysis and the impact of foreign banks on the growth of domestic countries and its implications regarding the allocation of capital and labor. The findings suggest that foreign presence exerts significant spillover effects and increased foreign banks appear to impel domestic banks to cut back lending. Regarding its impact on growth, the results show that although labor does not exert any visible effect on GDP growth, capital exerts a positive impact on output but only when foreign bank entrance is high. In the Romanian banking system foreign banks contributed to increase efficiency in the overall banking system, therefore, the Romanian government authorities should encourage the entry of new foreign banks (Andries et. al., 2013: 195).

Regarding the structure of this paper, besides the introductive chapter, the paper is structured in the following sections: section two provides an analysis regarding the structural evolution of the banking system in Romania under the impact of FDI, while the third section of the paper presents the performance of the banking sector in terms of profitability, followed by the main conclusions.

\section{The structural evolution of the banking system in Romania under the impact of FDI}

The integration of Romania to the European Union attracted several financial groups from the community space, which considered that the local business environment is suitable to open their units in our country. From this perspective, Romania, as a member of the EU, had a high growth potential, concerning the banking sector, context in which foreign banks moved to grow along with the market. The increasing competition in the banking market and the significant entry of foreign capital have turned Romania in one of the major markets facing actors of European size (Spulbar and Nitoi, 2012: 460-461).

The banking sector has played a determining role in Romania's transition process to the market economy, given that it mediates the interface between the real economy and the nominal economy, shifting to the institutionalized mechanisms of competition. The entry of foreign capital in the banking sector in Romania was carried out through the following: (a) the 
establishment of new branches of foreign banks in Romania and the forming of new banks with domestic capital; (b) the privatization of the banks owned by the state through acquiring the majority stake by the banks with foreign capital (Zaman and Vasile, 2006: 51). Out of 36 credit institutions in Romania at the end of 2015, 30 banks had foreign capital (total credit institutions with a majority foreign capital including branches of foreign banks), with a market share of $90.4 \%$ (share in net aggregate assets), of which an amount of $10.8 \%$ belonged to branches of foreign banks. During 2015, the largest share of net assets continued to be held by the credit institutions with Austrian majority (33.3\%), followed by those with French majority (13.5\%) and the ones owned by Greeks (10.6\%) (NBR, 2015: 94). At the end of 2014, Banca Transilvania entered from the category of institutions with a majority of domestic capital, to the category of banks with a majority of foreign capital as a result of purchasing of shares by the International Finance Corporation (NBR, 2015: 69). Between 2013 - 2015, the net assets of banks with domestic capital increased approximately 1.02 times, while for banks with majority foreign capital the increase was of approximately 1.05 times, so that banks with majority private capital, including branches of foreign credit institutions represent $91.7 \%$ as size of the market share (see Table 1 ).

Table 1: The market share of banks and branches of foreign banks

\begin{tabular}{|l|c|c|c|c|c|c|}
\hline \multirow{2}{*}{} & \multicolumn{5}{|c|}{$\mathbf{2 0 1 3}$} & \multicolumn{2}{c|}{$\mathbf{2 0 1 4}$} & \multicolumn{2}{c|}{$\mathbf{2 0 1 5}$} \\
\cline { 2 - 7 } & \multicolumn{1}{|c|}{$\begin{array}{c}\text { RON } \\
\text { mill. }\end{array}$} & $\%$ & $\begin{array}{c}\text { RON } \\
\text { mill. }\end{array}$ & $\%$ & $\begin{array}{c}\text { RON } \\
\text { mill. }\end{array}$ & $\%$ \\
\hline $\begin{array}{l}\text { Credit institutions with } \\
\text { domestic capital, of which: }\end{array}$ & 35473.9 & 9.8 & 36797.7 & 10.1 & 36342.7 & 9.6 \\
\hline $\begin{array}{l}- \text { with majority state-owned } \\
\text { capital }\end{array}$ & 30874.4 & 8.5 & 31857.9 & 8.7 & 31360.7 & 8.3 \\
\hline - with majority private capital & 4599.5 & 1.3 & 4939.8 & 1.4 & 4982.0 & 1.3 \\
\hline $\begin{array}{l}\text { Credit institutions with } \\
\text { majority foreign capital }\end{array}$ & 291721.8 & 80.6 & 291801.9 & 80.1 & 300204.8 & 79.6 \\
\hline $\begin{array}{l}\text { I. Credit institutions, } \\
\text { Romanian legal entities }\end{array}$ & 328088.8 & 90.6 & 328599.6 & 90.2 & 336547.5 & 89.2 \\
\hline $\begin{array}{l}\text { II. Branches of foreign credit } \\
\text { institutions }\end{array}$ & 34170.4 & 9.4 & 35543.7 & 9.8 & 40639.7 & 10.8 \\
\hline $\begin{array}{l}\text { Total credit institutions with } \\
\text { majority private capital, } \\
\text { including branches of foreign } \\
\text { credit institutions }\end{array}$ & 330491.7 & 91.3 & 332285.4 & 91.3 & 345826.5 & 91.7 \\
\hline $\begin{array}{l}\text { Total credit institutions with } \\
\text { majority foreign capital, } \\
\text { including branches of foreign } \\
\text { credit institutions }\end{array}$ & 325892.2 & 90.0 & 327345.6 & 89.9 & 340844.5 & 90.4 \\
\hline Total credit institutions (I+II) & 362259.2 & 100.0 & 364143.3 & 100.0 & 377187.2 & 100.0 \\
\hline
\end{tabular}

Source: own calculations and data processed based on NBR (2014), Annual Report , p. 76 and NBR (2015), Annual Report, p. 94

Concerning the degree of concentration of the banking system, the top five banks (Banca Comerciala Romana, BRD, Banca Transilvania, Raiffeisen Bank, UniCredit Bank), had a record of $57.9 \%$ on the market share by assets held on 31 December 2015, which shows a moderate level of concentration of the banking system. The concentration of the banking system calculated by the Herfindahl - Hirschman Index $(\mathrm{HHI})$, recorded in 2015 a value of 861 points, up from 797 points in 2014 (NBR, 2015: 93). 
By analyzing the structural evolution of the banking system in Romania, we can establish according to the Table 2, that the biggest share of the banking capital in Romania, $85.9 \%$ of the total capital of the banking system belongs to the credit institutions with a foreign majority capital and branches of foreign credit institution. The foreign capital of the credit institutions originates from the member states of the European Union.

Table 2: Credit institutions as a share in aggregate capital

\begin{tabular}{|c|c|c|c|c|c|c|}
\hline & \multicolumn{6}{|c|}{ Share/Endowment capital } \\
\hline & \multicolumn{2}{|c|}{2013} & \multicolumn{2}{|c|}{2014} & \multicolumn{2}{|c|}{2015} \\
\hline & $\begin{array}{l}\text { RON } \\
\text { mill. }\end{array}$ & $\%$ & $\begin{array}{l}\mathrm{RON} \\
\text { mill. }\end{array}$ & $\%$ & $\begin{array}{l}\text { RON } \\
\text { mill. }\end{array}$ & $\%$ \\
\hline $\begin{array}{l}\text { Credit institutions with domestic } \\
\text { capital, of which: }\end{array}$ & 3507.8 & 13.9 & 3771.0 & 13.7 & 3539.6 & 14.1 \\
\hline $\begin{array}{l}\text { - with majority state-owned } \\
\text { capital }\end{array}$ & 3035.0 & 12.0 & 3074.0 & 11.2 & 3081.0 & 12.3 \\
\hline - with majority private capital & 472.8 & 1.9 & 697.0 & 2.5 & 458.6 & 1.8 \\
\hline $\begin{array}{l}\text { Credit institutions with majority } \\
\text { foreign capital }\end{array}$ & 21308.6 & 84.3 & 23427.3 & 85.1 & 21281.3 & 84.6 \\
\hline $\begin{array}{l}\text { I. Credit institutions, Romanian } \\
\text { legal entities }\end{array}$ & 24949.8 & 98.7 & 27198.3 & 98.8 & 24820.9 & 98.7 \\
\hline $\begin{array}{l}\text { II. Branches of foreign credit } \\
\text { institutions }\end{array}$ & 324.1 & 1.3 & 323.4 & 1.2 & 321.9 & 1.3 \\
\hline $\begin{array}{l}\text { Total credit institutions with } \\
\text { majority private capital, } \\
\text { including branches of foreign } \\
\text { credit institutions }\end{array}$ & 22105.5 & 87.5 & 24447.7 & 88.8 & 22061.8 & 87.7 \\
\hline $\begin{array}{l}\text { Total credit institutions with } \\
\text { majority foreign capital, } \\
\text { including branches of foreign } \\
\text { credit institutions }\end{array}$ & 21632.7 & 85.6 & 23750.7 & 86.3 & 21603.2 & 85.9 \\
\hline Total credit institutions $(\mathrm{I}+\mathrm{II})$ & 25273.9 & 100.0 & 27521.7 & 100.0 & 25142.8 & 100.0 \\
\hline
\end{tabular}

Source: own calculations and data processed based on NBR (2014), Annual Report, p.76 and NBR (2015), Annual Report, p.94

Structural developments have been also characterized by carrying out important merger operations, and by sales of portfolios or stakes, which contributed to a strengthening of the local banking market. From this perspective, in April 2015 Volksbank Romania S.A. changed its ownership as a result of its acquisition by Banca Transilvania, and the merger was completed through absorption at the end of 2015. Also at the end of October 2015, the merger by absorption of OTP Bank Romania as absorbing company and Millennium Bank as the company being acquired was ended. In addition, there have been changes in the shareholding of the credit institutions, as was the case of UniCredit Bank Tiriac, where the majority shareholder (the Italian group UniCredit) has strengthened its position by acquiring a package of shares, the bank changing its name into UniCredit Bank. Another change in the structure of the Romanian banking system was the cessation of Montepio branches of Credito Credito-Instituicao Financeira Portugal in August and The Royal Bank of Scotland plc, Edinburgh, in late October (NBR, 2015: 93).

The volume of capital for the banking sector in Romania was at the end of $2015,8.6 \%$ lower than the previous year (from the amount of RON 27,521.7 million in December 2014 to the amount of RON 25,142.8 million in December 2015) this decrease being mainly because of the exit from the market of banks such as Millennium and Volksbank Romania. Given the accession of Romania to the EU and the liberalization of the services market, until May 30, 
2016 a number of 653 foreign institutions have notified the National Bank of Romania (NBR) of the intention to carry out banking activities in Romania as it follows: 284 banks, 5 non banking financial institutions, 85 institutions issuing electronic money and a total of 279 of payment institutions (NBR, 2015: 95).

Table 3: The share in capital of credit institutions by country of origin in 2015

\begin{tabular}{|l|c|}
\hline Country of origin & In total foreign capital (\%) \\
\hline France & 21.5 \\
\hline Germany & 19.3 \\
\hline Netherlands & 17.7 \\
\hline Sweden & 13.1 \\
\hline Italy & 6.8 \\
\hline Cyprus & 6.5 \\
\hline Greece & 5.3 \\
\hline Austria & 3.5 \\
\hline United Kingdom & 3.0 \\
\hline Poland & 2.3 \\
\hline Bulgaria & 1.0 \\
\hline Total & 100.0 \\
\hline
\end{tabular}

Source: data processed based on NBR (2015), Annual Report, p.108

At the end of 2015, depending on the origin of the capital invested in banks on the Romanian market (Table 3) France, Germany and the Netherlands have a share of $58.5 \%$ of the total foreign capital, the difference of $41.5 \%$ belonging to the other countries (Sweden, Italy, Cyprus, Greece, Austria, UK, Poland and Bulgaria).

Concerning the total amount of foreign capital, it recorded the amount of RON 756.8 million, a decreasing value compared to 2014 by RON 104.7 million, and also by $12 \%$ (NBR, 2015: 108).

\section{The performance of the banking sector in terms of profitability}

The quantification of performance is important because the profit is a way of protection against unforeseen losses, capital consolidation, and last, but not least, to increase profits by reinvesting it.

In terms of performances recorded in 2015 , the value of profitability indicators according to assets or return on assets (ROA) and the return based on ownership equity or return on equity (ROE) was positive.

The profitability of the Romanian banking system after a loss of RON 4667 million at the end of 2014 has come to its self, so that 2015 ended with a net profit of RON 4474.7 million because of the reduction of the cost covering the credit risk and the positive influence of merger operations. Against this background the ROE indicator, determined as a ratio between the net income (after taxes) and the total of equity calculated on an average amount, recorded a value of $11.8 \%$ in December 2015 , while the ROA indicator, calculated as ratio between the net income and the total of banking assets on an average amount, stood at $1.2 \%$ at the end of 2015 (NBR, 2015: $100-102)$.

At the level of credit institutions, 22 credit institutions closed the year with profit, while 14 credit institutions reported losses (NBR, 2015: 102).

In 2015 , the top ten banks in the banking sector of Romania held $71.6 \%$ of the assets, (Table 4) while the remaining 26 banks held a share of only $28.4 \%$ of the market. 
Table 4: The top 10 largest banks in Romania in 2015

\begin{tabular}{|l|l|c|c|}
\hline Rank & \multicolumn{1}{|c|}{ Bank } & $\begin{array}{c}\text { Net assets } \\
\text { (RON mill.) }\end{array}$ & $\begin{array}{c}\text { The market share } \\
\text { in terms of assets in 2015 (\%) }\end{array}$ \\
\hline 1 & Banca Comercială Română & 59460.9 & 15.8 \\
\hline 2 & BRD - Groupe Société Générale & 49192.9 & 13.0 \\
\hline 3 & Banca Transilvania & 47382.9 & 12.6 \\
\hline 4 & Raiffeisen Bank & 31443.1 & 8.4 \\
\hline 5 & UniCredit Bank & 30611.8 & 8.1 \\
\hline 6 & Alpha Bank & 15005.9 & 4.0 \\
\hline 7 & Bancpost & 11386.9 & 3.0 \\
\hline 8 & Garanti Bank & 9580.8 & 2.5 \\
\hline 9 & OTP Bank & 8588.4 & 2.3 \\
\hline 10 & Piraeus Bank & 7093.0 & 1.9 \\
\hline
\end{tabular}

Source: data processed based on NBR (2015), Annual Report, p.101

Banca Comercială Română, BRD - Groupe Société Générale and Banca Transilvania are in 2015 the main banks in the Romanian banking system, with a major market share.

It is worthy of note that the main European banks, with regional development strategies that have asserted themselves in the banking system in Romania, are also found in other countries all around Central and Eastern Europe as it follows: Erste Bank, Societe Generale, Raiffeisen Bank, UniCredit Bank who preferred to purchase some banks already existent on the market without opening subsidiaries (Spulbar and Nitoi, 2012: 452).

\section{In conclusion}

In the last few years, we can distinguish the recording of a new trend, the market shares held by foreign banks have grown making against the domestic segment and also continued to dominate the structure of the banking system in Romania, thus triggering a strong competition between credit institutions. Currently the top 5 banks in the Romanian banking system, namely: Romanian Commercial Bank, BRD - Groupe Société Générale and Banca Transilvania, Raiffeisen Bank, UniCredit Bank own together $57.9 \%$ on the market share by assets in 2015.

Regarding the high share of banks with foreign capital including branches, over $85 \%$ of the total capital of the Romanian banking sector, it can have beneficial effects on one hand but on the other hand, it also has risks.

In terms of benefits, foreign banks represent important channels of transfer of productive resources, managerial and organizational skills and finally yet importantly, the experience accumulated internationally, thus contributing to increased competition in the banking market in Romania.

In terms of risks, we believe the impact may have effects considering that the highest share of capital in the Romanian banking system is owned by foreign shareholders, and in these conditions, the banking sector becomes dependent on the economic situation in the countries of origin, context in which, there is a risk to our country's economy through the so called "contagion effect".

Another downside can be noticed through the fact that the withdrawal of foreign banks can cause significant imbalances on the local market as a result of the exit of the capital from the Romanian economy.

Note that in the context of the global economic crisis, the banking system in Romania had a relatively modest evolution but which has held up well, despite the international vulnerabilities. 


\section{References}

Andries, A., Mehdian, S., Stoica, O. (2013). 'Impact of European Integration on Efficiency and Productivity Growth of Romanian Banks', Engineering Economics, vol. 24, no. 3, pp. 187-197.

Balaj, D. (2015). 'A Comparison of Financial Performance of Domestic and Foreign banks in Kosovo by Using DuPont Model', Acta Universitatis Danubius. CEconomica, vol.11, no. 6, pp. 71-86.

Ghosh, S. (2016). 'Foreign banks in MENA countries: how important? How relevant?', Journal of Economic and Administrative Sciences, vol. 32, no 1, pp.77 - 98.

Kandilov, I. T., Leblebicioğlu, A. and Petkova, N. (2016). 'The impact of banking deregulation on inbound foreign direct investment: Transaction-level evidence from the United States', Journal of International Economics, vol.100, pp. 138-159.

Morutan, R. A. and Badulescu, D. (2016). 'State-Owned, Acquisition Or Greenfield Banks In The New Eu Member States. A Post-Crisis Analysis', Oradea Journal of Business and Economics, vol. 1, no. 2, pp. 62-71.

Mulyaningsih, T., Daly, A. and Miranti, R. (2015). 'Foreign participation and banking competition: Evidence from the Indonesian banking industry', Journal of Financial Stability, vol. 19, pp. 70-82.

Mutinelli, M. and Piscitello, L. (2001). 'Foreign direct investment in the banking sector: the case of Italian banks in the'90s', International Business Review, vol. 10, no. 6, pp. 661-685. National Bank of Romania (2014). Annual Report [online], available from: http://www.bnr.ro/Regular-publications-2504.aspx. [15.07.2016].

National Bank of Romania (2015). Annual Report [online], available from: http://www.bnr.ro/Regular-publications-2504.aspx. [15.07.2016].

National Bank of Romania (2015). Financial Stability Report [online], available from: http://www.bnr.ro/Regular-publications-2504.aspx. [15.07.2016].

Niepmann, F. (2015). 'Banking across borders', Journal of International Economics, vol. 96, no. 2, pp. 244-265.

Popovici, A. N. (2013). 'Mergers, Acquisitions and Banking Consolidation in Central and Eastern Europe', CES Working Papers, vol.4, pp. 567-576.

Simpasa, A. M. (2013). 'Increased foreign bank presence, privatisation and competition in the Zambian banking sector', Managerial Finance, vol. 39, iss: 8, pp. $787-808$.

Spulbar, C. and Nitoi, M. (2012). Sisteme bancare comparate / Comparative analysis of baking systems, Craiova: Sitech.

Van Horen, N. (2007). 'Foreign banking in developing countries; origin matters', Emerging Markets Review, vol. 8, no. 2, pp. 81-105.

Weill, L. (2003). 'Banking efficiency in transition economies', Economics of transition, vol. 11, no. 3, pp. 569-592.

Zaman, G., Vasile, V. (2006). Transferul tehnologic şi investiţiile-priorităţi ale dezvoltării durabile / Technological transfer and investments - priorities for sustainable development, Bucuresti: Expert-CIDE.

\section{Bio-note}

Vasile Cocriş is currently Vice-Dean and Professor at the Faculty of Economics and Business Administration of the "Alexandru loan Cuza" University of lasi, Romania. He was a visiting professor at the University of Omaha, USA, University of Bologna, Italy, and University Nijmegen, Netherlands and his scientific articles have been published in various national and international journals. 
Oradea Journal of Business and Economics, Volume II Issue 1

Published on March 2017

Maria-Ramona Sârbu is PhD student in Finance at the Doctoral School of Economics and Business Administration of the "Alexandru loan Cuza" University of lasi, Romania, being supervised by Prof. Dr. Vasile Cocriş. As a PhD student, her research interests are related to international trade, economic growth, regional development and corporate social responsibility. 